Avtandil Khachapuridze, Associate Professor Akaki Tsereteli State University Georgia, Kutaisi ORCID: 0000-0002-2838-1488

\title{
STAFF MOTIVATION AS A SOURCE OF COMPETITIVENESS OF HOTEL BUSINESS ESTABLISHMENTS
}

The article deals with the theory of personnel management and labour motivation, taking into account the specifics of the hotel business; provides recommendations for improving the level of corporate culture for the use of modern motivational systems in a particular enterprise.

Keywords; hotel and restaurant business, hospitality industry, marketing research, staff motivation, corporate culture.

Relevance of research topic. Hotel and restaurant complex is a living organism, in which the level of service plays a significant role. It should be noted that a direct relationship between the consumer and the seller of services is in the hospitality industry [1]. Therefore, for hotels, first of all, the number of services offered as their quality that matters it is not so much. It is a high-quality service that creates comfortable conditions for guests. Therefore, the successful use of creative potential is largely determined by the development of evidence-based recommendations for improving the effectiveness of personnel, including the selection, placement of personnel, their activities, as well as staff motivation [2].

The fact that the successful development of any hotel is impossible without the existence of an effective, motivated and success-oriented team is not in doubt. The successful experience of hotel companies shows that industry employees should be considered primarily as a source of ideas, so HR management should be based on the individual psychological characteristics of employees [3].

The actuality of research in this direction lies in the fact that today staff motivation is almost the only source of competitiveness, which determines the role of human resources in the enterprise [4].

Formulation of the problem. Motivation is key element of HR management. At the same time, the relevance of studying the motivation system at the enterprises of the hotel business is justified by the fact that the hotel industry plays a leading role in the presentation of domestic tourist products on the world market of tourist services. The creation of a highly efficient hotel economy affects both the development of the tourism industry as a whole, and the complex of industries that serve the tourism sector. 
The concept of staff motivation is not separated from the concept of corporate culture and is constantly closely interrelated. They together constitute a system of personnel management of the enterprise, which includes the following elements: factors of staff motivation, organizational culture, leadership style, satisfaction with work conditions, team spirit, the individual structure of needs, the employee representation on the evaluation criteria of labour, the aims of the enterprise, its future, etc.

An effective system of staff motivation is not only the most important factor in the economic success of modern hotel business establishments, not only a tool for improving the efficiency and productivity of staff but also a socially-oriented management function that is addressed to each employee to increase their work motivation and meet their needs through a system of material incentives. Investment in human resources becomes a long-term factor in increasing the competitiveness and survival of the enterprise [5].

Analysis of recent researches and publications. Study of foreign and domestic special literature on theoretical and methodological aspects of motivation and incentives for staff, the formation of approaches to improving productivity, and the analysis of factors of effective motivation and incentives for staff indicates the undoubted interest of scientists in this issue. Outstanding foreign and domestic scientists have devoted their works to the problems of motivation and stimulation of personnel.

A significant contribution to the development of the theory and practice of staff motivation was made by representatives of the scientific school of management F. Taylor, F. Gilbreth and L. Gilbreth, G. Emerson, and E. Mayo. Further formation of scientific approaches to the problem of motivation was enriched by meaningful and process motivational theories, the authors of which are A. Maslow, F. Hertzberg, D. McGregor, D. McClelland, G. Tsekhanovetsky, N. Volsky, N. Tugan-Baranovsky, and others. The consideration of labour motivation with regard to the specifics of the hotel business is covered in the works of G. O. Sabadosh, O. M. Sukach, L. I. Nechayuk, N. O. Telesh.

Despite the significant contribution of scientists to the study of the essence of motivation and incentive of personnel, their features, and distinctive characteristics, as well as determining their place in effective enterprise management and improving innovation, the problem of solving this issue still remains open. That is why the definition of scientific approaches to motivation and stimulation of personnel in the effective management of the enterprise and increase its innovation activities require additional research

Theoretical analysis of the problem of motivation allowed us to determine the most significant factors that affect the motivation of staff in the hotel and restaurant business. There are a lot of motivating factors due to the fact that the process of production, sale and organization of consumption of a hotel product is complex, changeable and multi-sided.

Today, in order to apply certain methods and theories of motivation, it is necessary to understand what drives a person, what is at the heart of his motives. The 
motive is «inside» the person has a «personal» character, depends on a set of external and internal factors in relation to the person, as well as on the action of other motives that arise in parallel with it. Human behaviour, as a rule, is determined not by one motive, but by their totality, within which they are in a specific relationship to each other in terms of the level of interaction per person. Hence, the motivational structure of an individual is the basis for turning certain actions into life. This structure is characterized by certain stability, but at the same time it can change, including consciously, depending on the person's upbringing, education, and other factors [6].

\section{Presenting main material}

For the hospitality industry, one of the most important tasks is the formation of an integrated system of professional qualifications, which should take into account both the traditional experience of hotel and restaurant management and the latest technological achievements introduced in the best national and international hotels $[7,8]$. Therefore, the purpose of this study is to study the theory of personnel management in hotel and restaurant complexes and develop recommendations for improving the level of corporate culture for the use of modern motivational systems in a particular enterprise, namely, the hotel and restaurant complex «Bagrat 1003» in the city of Kutaisi.

Research results showed that the most significant methods of the material motivation of staff were marked by preferential food (31\%) and bonuses $(25 \%)$. Among the most important moral methods are health insurance $(30 \%)$ and career opportunities $(22 \%)$.

Marketing research of the corporate culture in the hotel and restaurant complex «Bagrat 1003» has shown that some of its elements, namely incentive systems, are at a fairly low level. Therefore, the research results formed the basis for conclusions and proposals for the implementation (correction) of the system of personnel motivation in the institution with the overall goal of improving its corporate culture.

At the moment, a very important element of material motivation is the timely payment of wages. Workers work more effectively if they are confident in the stability of their earnings, especially in difficult moments of economic crisis. It is established that bonuses are a fairly significant factor of motivation, but they are almost not used in this enterprise. Therefore, the use of one-time bonuses is proposed in order to encourage employees to work more effectively. For a more influential effect, each award should be presented by a direct supervisor and accompanied by a conversation and congratulations from the employee.

According to the results of the research, it was found that the company does not have any employee adaptation programs. Therefore, it is recommended to develop and apply adaptation programs for new employees in the institution, as well as to appoint responsible persons who will implement them. These programs should include functional responsibilities, work discipline, norms and rules of behaviour, existing traditions, and so on.

In the course of conducting research, it was revealed that the majority of the staff strives for training, professional development with a view to possible career 
growth. It is necessary to allow employees to reach their potential. It is the management that should apply systematic training and training programs for employees, helping to fully develop their capabilities in the enterprise.

One of the most popular motivation strategies today is creating a team. It is necessary to make employees feel that their contribution is appreciated; to recognize that no goal can be achieved without the participation of all those who work in this direction, regardless of their position in the hierarchy; to create an atmosphere of respect and trust among team members; to ensure more effective communication between employees.

Conclusions. Research of the process of personnel motivation, identification and solution of problems related to its improvement, is certainly relevant, especially in the hospitality industry, where the competitiveness of enterprises largely depends on the level of employee motivation. At the same time, a high level of staff motivation for quality work in the hospitality industry is not just desirable, but a necessary indicator, because the very existence of the enterprise is directly dependent on the quality of work of its staff.

\section{REFERENCES}

1. Kharebova K.A. Nykolskaia E.Yu. Kachestvo obsluzhivaniya: sovremennye podkhody $\mathrm{k}$ oczenke $\mathrm{i}$ sovershenstvovaniyu na predpriyatiyakh industrii gostepriimstva, Nauchnye trudy Swold. 2015, t.12 №1 (38).

2. Kyrnos K. Sistema KPI i motivacziya. // Oteler i restorator. 2015. №5 (49). pp. 52-55.

3. Montagne S. Les fonds de pension. Entre protection sociale et speculation financiere. Paris: Odile Jacob, 2012.

4. Genkin B. M. Motivacziya i organizacziya e`fektivnoj raboty (teoriya $\mathrm{i}$ praktika): monografiya / Genkin B. M. M.: INFRA-M, 2016. p. 352

5. Kovaleva N.I. Nikolskaya E.Yu. Innovaczionnye strategii upravleniya personalom na predpriyatiyakh industrii gostepriimstva, Soczialno-ekonomicheskie i pravovye osnovy razvitiya ekonomiki: kollektivnaya monografiya, Ufa: Aeterna, 2015 pp.76-89/

6. Underhill G. R. D. Global Financial Architecture, Legitimacy, and Representation: Voice for Emerging Markets // Garnet Policy Brief. January 2012. Number 3. P. II.

7. World Tourism Organization UNWTO [Electronic recourse]. - Mode of access: http://www2.unwto.org/

8. World Travel \& Tourism Council (WTTC) [Electronic recourse]. - Mode of access: https://www.wttc.org/ 